\title{
Active Transport of Benzoate in Pseudomonas putida
}

\author{
By J. R. THAYER*† AND M. L. WHEELIS \\ Department of Bacteriology, University of California, Davis, California 95616, U.S.A.
}

(Received 9 November 1981)

\begin{abstract}
Benzoate uptake in Pseudomonas putida is mediated by an active transport system capable of accumulating benzoate against a 150 -fold concentration gradient when subsequent metabolism is blocked by mutation. Initial benzoate transport rates are inhibited by CCCP, sodium azide, arsenate and DCCD. Uptake is stimulated by including a respirable carbon source during preincubation of the bacteria. The initial uptake rate and the ATP pool levels are not correlated and no periplasmic components were found to bind benzoate. These observations indicate that benzoate uptake is energized by the membrane potential, rather than by ATP hydrolysis.
\end{abstract}

\section{INTRODUCTION}

Pseudomonas putida dissimilates benzoic acid through the catechol branch of the $\beta$-ketoadipate pathway (Ornston \& Stanier, 1966; Reiner, 1971). Mandelate catabolism also occurs through this pathway by conversion to benzoate (Hegeman, 1966). These compounds are weak, relatively hydrophobic acids and were initially presumed to gain entry into cells by diffusion (Rottenberg, 1975). We reported (Thayer \& Wheelis, 1976) that benzoate entry into $P$. putida is mediated by a saturatable uptake system whose synthesis (or function) is governed by a gene designated benP. Mutation in this gene drastically reduced the ability to accumulate benzoate intracellularly, and prevented growth when benzoate, but not mandelate, was the carbon source. Mutation in genes encoding proteins catalysing subsequent steps in benzoate catabolism did not appear to limit intracellular benzoate accumulation (Thayer \& Wheelis, 1976).

While varying assay conditions for possible improvements, we noticed that addition of a respirable carbon source improved uptake rates and substantially decreased the observed $K_{\mathrm{m}}$ for benzoate. This indicated that active transport of benzoate occurred. We now report that benzoate transport is active and most probably energized by the membrane potential rather than by ATP hydrolysis.

\section{METHODS}

Organisms. Pseudomonas putida PRS1, the type strain of this species (Stanier et al., 1966), was the parent organism. PRS2003, a mutant derived from PRS1, bears a large deletion in the cat $R-B$ region of the $P$. putida chromosome and does not grow on benzoate [the cat genes are required for its catabolism (Wheelis \& Ornston, 1972)]. The benP mutant PRS2017 is deficient in benzoate transport and hence does not grow on benzoate (Thayer \& Wheelis, 1976).

Cultural conditions. Cultures were inoculated from L agar slants (Lennox, 1955) into Hutner's mineral base (Cohen-Bazire et al., 1957) containing succinate, quinate, DL-mandelate or benzoate as a carbon source. Induction

† Present address: Crocker Nuclear Laboratory, University of California, 95616, U.S.A.

Abbreviations: CCCP, carbonyl cyanide $m$-chlorophenylhydrazone; DCCD, $N, N^{\prime}$-dicyclohexylcarbodiimide. 
of benzoate transport activity required inclusion of mandelate or benzoate if neither was serving as the carbon source.

Uptake assays. Organisms were harvested and washed as previously described (Thayer \& Wheelis, 1976) except that the phosphate buffer $\mathrm{pH}$ was 6.8 . The washed cell suspension was diluted to $0.1 \mathrm{mg}$ dry wt $\mathrm{ml}^{-1}$ with prewarmed $\left(30^{\circ} \mathrm{C}\right)$ media containing succinate $(35 \mu \mathrm{M})$ or catechol $(54 \mu \mathrm{M})$ as a respirable carbon source, and preincubated for $17 \mathrm{~min}$. Inhibitors of energy metabolism, when present, were added $60 \mathrm{~s}$ prior to addition of $\left[{ }^{14} \mathrm{C}\right.$ benzoate. Labelled benzoate was added to the final concentrations indicated. Samples $(1 \mathrm{ml})$ were filtered through $25 \mathrm{~mm}$ diameter HAWP Millipore filters $0.3,0.6,0.9$ and $1.2 \mathrm{~min}$ after adding the label. Filtered cells were washed with $7 \mathrm{ml}$ prewarmed $\left(30^{\circ} \mathrm{C}\right.$ ) PAB buffer (Thayer \& Wheelis, 1976) and the filters removed from the vacuum $60 \mathrm{~s}$ after adding the wash buffer. The filters were dried under IR light and counted in a toluene-based scintillation fluid (Patterson \& Green, 1965). Counts bound to uninduced (succinate-grown) cells were subtracted from those bound to induced cells to correct for non-specific binding and diffusion.

Oxygen uptake assays. Cells grown to mid-exponential phase with $15 \mathrm{~mm}$-quinate (control) or $15 \mathrm{~mm}$-quinate plus $5 \mathrm{~mm}$-benzoate were harvested by centrifugation, washed twice and resuspended in the growth medium containing chloramphenicol $\left(200 \mu \mathrm{g} \mathrm{ml}^{-1}\right)$, but lacking a carbon source. Two $\mathrm{ml}$ of this suspension $(0.25 \mathrm{mg} \mathrm{dry}$

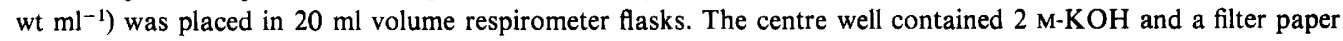
wick to trap $\mathrm{CO}_{2}$ and the side-arm held $4.1 \mu \mathrm{mol}$ sodium benzoate in $50 \mu \mathrm{l}$ of resuspension medium. Oxygen uptake was measured manometrically in a Gilson differential respirometer at $30^{\circ} \mathrm{C}$ for 60 min after mixing benzoate with the bacteria.

Determination of ATP pools. Cells grown under the same conditions as used for transport studies were harvested and washed as before, then resuspended in $30^{\circ} \mathrm{C}$ growth medium lacking a nitrogen source. Metabolic inhibitors, when present, were included at the indicated concentrations for $1 \mathrm{~min}$ in the transport preincubation medium prior to Vortex extraction $\left[2 \mathrm{ml}\right.$ cell suspension in $0.5 \mathrm{ml} 30 \%(\mathrm{v} / \mathrm{v}) \mathrm{HClO}_{4}$ on ice]. The extracted cells were allowed to stand, on ice, for $10 \mathrm{~min}$, neutralized with $1 \mathrm{M}-\mathrm{KOH}$ and the precipitated $\mathrm{KClO}_{4}$ removed by centrifugation $(1200 \mathrm{~g}, 5 \mathrm{~min})$. Samples of the supernatant $(0.2 \mathrm{ml})$ were assayed for ATP using the luciferin-luciferase reaction according to Collins (1974).

CCCP quenched the light emitted too severely to allow measurement of ATP pools in the presence of this inhibitor.

Chemicals. All chemicals obtained commercially were of the highest purity available. Uniformly labelled $\left[{ }^{14} \mathrm{C}\right.$ lbenzoate $\left(108 \mathrm{mCi} \mathrm{mmol}^{-1} ; 4.0 \mathrm{GBq} \mathrm{mmol}^{-1}\right)$ was obtained from Amersham-Searle. The metabolic inhibitors, CCCP and DCCD, were kindly provided by R. S. Criddle.

\section{RESULTS AND DISCUSSION

$$
K_{\mathrm{m}} \text { and } V_{\max } \text { determinations }
$$

Values of $K_{\mathrm{m}}$ and $V_{\max }$ were determined with the modified assay using benzoate concentrations between 10 - and 135- $\mu \mathrm{M}$. Lineweaver-Burk plots of the data obtained gave a $K_{\mathrm{m}}$ of $20 \mu \mathrm{M}$ (compared to our previously published value of $100 \mu \mathrm{M}$ ) and a $V_{\max }$ of $30 \mathrm{nmol}$ $\mathrm{min}^{-1}(\mathrm{mg} \text { dry } \mathrm{wt})^{-1}$. Linear regression analysis gave a coefficient of determination $\left(r^{2}\right)$ greater than 0.99 .

These kinetic parameters indicate that a $P$. putida cell can transport about $1.4 \times 10^{5}$ molecules of benzoate in $1 \mathrm{~s}$. Hydroxyproline and succinate are transported into $P$. putida at a maximal rate of 2.9-3.0 $\times 10^{4}$ molecules per cell s ${ }^{-1}$ (Gryder \& Adams, 1970; Dubler et al., 1974). Thus, if transport were rate limiting for the dissimilation of these carbon sources, benzoate would be the best of these compounds. However, succinate yields the highest growth rate, so transport cannot be the rate-limiting factor for growth on benzoate in $P$. putida.

A previous comparison of benzoate uptake by the wild-type and benP mutant PRS2017 indicated that PRS2017 accumulated benzoate only to $9 \%$ of the level of the wild-type in 5 min (Thayer \& Wheelis, 1976). In the present study, comparison of the initial rate of benzoate transport by these strains indicated that the mutant had less than $1 \%$ of the activity of the wild-type, $[<100 \text { c.p.m. (mg dry wt) })^{-1} \mathrm{~min}^{-1}$ for PRS2017 and 11300 c.p.m. (mg dry $\mathrm{wt})^{-1} \mathrm{~min}^{-1}$ for PRS 1]. Thus the increase in ability to transport benzoate under the new conditions does not extend to the benP mutant. The increase in affinity and velocity of this transport system apparently resulting from the inclusion of a respirable carbon source during the preincubation indicates that this is probably an active transport system. 
Table 1. Oxygen consumption due to benzoate oxidation by P. putida strains grown on quinate $(15 \mathrm{mM})$ and benzoate $(5 \mathrm{~m} \mathrm{M})$

\begin{tabular}{lcc}
\multicolumn{1}{c}{ Strain } & Genotype & $\begin{array}{c}\mathrm{O}_{2} \text { consumption rate } \\
{\left[\mu \mathrm{min}^{-1}(\mathrm{mg} \mathrm{dry} \mathrm{wt})^{-1}\right]^{*}}\end{array}$ \\
PRS1 & Wild-type & $13 \cdot 22$ \\
PRS2017 & benP1106 & 0.212 \\
PRS2003 & catB-RIIII & 0.064
\end{tabular}

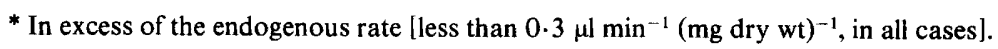

Table 2. Accumulation of $\left[{ }^{14} \mathrm{C}\right]$ benzoate by $P$. putida after 20 min incubation

Organisms were grown on quinate plus benzoate.

$\begin{array}{lccc}\text { Strain } & {\left[{ }^{14} \mathrm{C}\right] \text { Benzoate }_{\text {(out) }}} & {\left[{ }^{14} \mathrm{C}\right] \text { Benzoate }_{\text {(in) }}} & { }^{14} \mathrm{C}_{\text {(in) }} /{ }^{14} \mathrm{C}_{\text {(out) }} \\ \text { PRS1 } & 4.3 \mu \mathrm{M} & 1.75 \mathrm{mM} & 400 \\ \text { PRS2003 } & 4.3 \mu \mathrm{M} & 0.65 \mathrm{mM} & 148\end{array}$

\section{Accumulation of intracellular benzoate}

If benzoate transport is active, cells having the permease should accumulate intracellular benzoate against a concentration gradient. To demonstrate such an accumulation, we used a mutant blocked in the subsequent metabolism of benzoate.

The initial step in benzoate metabolism is the addition of molecular oxygen by a dioxygenase (Reiner \& Hegeman, 1971; Stanier et al., 1966). No mutants blocked in this step are available in $P$. putida. However, blocks later in the pathway can effectively prevent oxygenation of benzoate by an unknown mechanism, as shown in Table 1 , in which oxygen consumption by strain PRS2003 is compared to that of the wild-type and that of the benP mutant. Negligible amounts of oxygen were consumed by either mutant, indicating that benzoate oxidation is completely blocked in both strains by the inability of PRS2017 to transport benzoate and the inability of PRS2003 to metabolize it.

The volume of an average $P$. putida cell growing with a generation time of $60 \mathrm{~min}$ (e.g. quinate or benzoate as carbon and energy source) has been determined by particle sizing techniques to be $1.45 \mathrm{fl}$ (W. D. Rubenstein, personal communication). The intracellular concentration of $\left[{ }^{14} \mathrm{C}\right]$ benzoate or its metabolic derivatives can thus be estimated. When $P$. putida cultures grown on quinate in the presence of benzoate are permitted to take up $\left[{ }^{14} \mathrm{C}\right]$ benzoate for $20 \mathrm{~min}$, an intracellular accumulation of radioactivity occurs. Table 2 shows the extent of this accumulation in strains PRS 1 and PRS2003. PRS 1 accumulates ${ }^{14} \mathrm{C}$ to 400 -fold the initial extracellular level in $20 \mathrm{~min}$ when labelled benzoate is present at $4 \mu \mathrm{M}$. PRS2003, which cannot dissimilate carbon from benzoate, accumulates ${ }^{14} \mathrm{C}$ to 150 times its extracellular concentration. These estimates are based on total cell volume rather than on the intracellular water volume and therefore represent minimum estimates, indicating that, when metabolism is blocked, $P$. putida is capable of accumulating benzoate against a large concentration gradient.

\section{Effects of inhibitors of energy metabolism on benzoate transport and ATP pools}

To gain further evidence that benzoate transport is active, we exposed cell suspensions to inhibitors of energy metabolism, then measured their ATP levels and their ability to take up benzoate. Table 3 shows the effect of CCCP, azide, arsenate and DCCD on the initial rates 
Table 3. Effect of 1 min exposure of cells to metabolic energy inhibitors on ATP pools and initial rates of benzoate transport

\begin{tabular}{|c|c|c|c|c|}
\hline Inhibitor & $\begin{array}{c}\text { ATP } \\
{\left[\mathrm{nmol}(\mathrm{mg} \text { dry } w t)^{-1}\right]}\end{array}$ & $\begin{array}{l}\text { Percentage of } \\
\text { control pool size }\end{array}$ & $\begin{array}{c}{\left[{ }^{14} \mathrm{C} \mid \text { Benzoate }\right.} \\
\left.\text { [c.p.m. }(\mathrm{mg} \text { dry wt) })^{-1}\right]^{*}\end{array}$ & $\begin{array}{l}\text { Percentage of } \\
\text { control value }\end{array}$ \\
\hline None & 1.43 & 100 & 17550 & 100 \\
\hline $48 \mu \mathrm{M}-\mathrm{CCCP}$ & + & $\dagger$ & 1500 & 9 \\
\hline $4.9 \mathrm{~mm}$-Azide & 0.41 & 29 & 3640 & 20 \\
\hline $9.7 \mathrm{mM}^{-\mathrm{AsO}_{4}}$ & 1.00 & 70 & 4797 & 27 \\
\hline $1.18 \mathrm{~mm}-\mathrm{DCCD}$ & 1.39 & 97 & 4483 & 25 \\
\hline
\end{tabular}

of benzoate transport and the formation of ATP pools when included in the preincubation mixture for $1 \mathrm{~min}$. The proton ionophore, CCCP, which dissipates the proton gradient across membranes (Ramos et al., 1976; Johnston et al., 1977), depressed the initial transport rate to about $10 \%$ of the control value. Sodium azide, arsenate and DCCD have complex effects (Robertson \& Boyer, 1955; Mitchell \& Moyle, 1971; Gutowski \& Rosenberg, 1976; Reynafarje et al., 1976; Gerdes et al., 1977; Rosenberg et al., 1977). These inhibitors each reduced benzoate uptake by $70-80 \%$, but reduced the ATP pools by $70 \%$ (azide), $30 \%$ (arsenate) and 3\% (DCCD). Clearly the benzoate transport rate is not a specific correlate of the ATP concentration.

Attempts to obtain benzoate binding proteins from concentrated cold osmotic shock fluids of $P$. putida according to the method of Stinnet \& Eagen (1975) and identify these by equilibrium dialysis (Furlong et al., 1972) were unsuccessful (unpublished observations).

The stimulation of activity and affinity of the benzoate permease system by respiration, the marked inhibition of transport by transient exposure to the proton ionophore, CCCP, and by azide, arsenate and DCCD, the accumulation of labelled benzoate against a concentration gradient by mutants incapable of dissimilating transported benzoate, the failure of transport to correlate with ATP pool sizes, and our inability to demonstrate the presence of benzoate binding proteins in periplasmic shock fluid (Berger \& Heppel, 1974), all indicate that benzoate transport in $P$. putida is active and probably energized by the membrane potential.

This work was supported by NIH grant GM 18916 (to M.L.W.) and predoctoral training grant GM1041 (to J.R.T.). We are grateful to W. D. Rubenstein for cell volume determinations and R. S. Criddle for the generous gift of some of the inhibitors.

\section{REFERENCES}

Berger, B. A. \& Heppel, L. A. (1974). Different mechanisms of energy coupling for the shock sensitive and shock resistant amino acid permeases of Escherichia coli. Journal of Biological Chemistry 249, 7747-7755.

Cohen-Bazire, G., Sistrom, W. R. \& Stanier, R. Y. (1957). Kinetic studies of pigment synthesis by non-sulphur bacteria. Journal of Cellular and Comparative Physiology 49, 25-68.

Collins, J. K. (1974). Regulation of growth and biosynthesis in Pseudomonas putida. Ph.D. thesis, National University of Ireland, University College, Cork, Ireland.

Dubler, R. E., Toscano, W. A., Jr \& Hartline, R. A. (1974). Transport of succinate by Pseudomonas putida. Archives of Biochemistry and Biophysics $160,422-429$.

Furlong, C. F., Morris, R. G., Kandrach, M. \& Rosen, B. P. (1972). A multichamber equilibrium dialysis apparatus. Analytical Biochemistry 47, 514-526.

Gerdes, R. G., Strickland, K. P. \& Rosenberg, H. (1977). Restoration of phosphate transport by the phosphate binding protein in spheroplasts of Escherichia coli. Journal of Bacteriology 131, 512-518.

Gryder, R. M. \& AdAms, E. (1970). Properties of the inducible hydroxyproline transport system of Pseudomonas putida. Journal of Bacteriology 101, 948-958.

Gutowski, S. J. \& Rosenberg, H. (1976). Effects of 
dicyclohexylcarbodiimide on proton translocation coupled to fumarate reduction in anaerobically grown cells of Escherichia coli K12. Biochemical Journal 160, 813-816.

Hegeman, G. D. (1966). Synthesis of the enzymes of the mandelate pathway by Pseudomonas putida. I. Synthesis of enzymes by the wild type. Journal of Bacteriology 91, 1140-1154.

Johnston, R., Scharf, S. \& CRIDdle, R. S. (1977). Reversal of oligomycin inhibition of mitochondrial ATPase by ionophoric compounds. FEBS Letters 75, 213-216.

LenNOX, E. S. (1955). Transduction of linked genetic characters of the host by phage P1. Virology 1 , 190-206.

Mitchell, P. \& Moyle, J. (1971). Activation and inhibition of mitochondrial adenosine triphosphatase by various anions and other agents. Journal of Bioenergetics 2, 1-11.

Ornston, L. N. \& Stanier, R. Y. (1966). The conversion of catechol and $\beta$-ketoadipate by Pseudomonas putida. I. Biochemistry. Journal of Biological Chemistry 241, 3776-3786.

Patterson, M. S. \& Greene, R. C. (1965). Measurement of low energy beta emitters in aqueous solution by liquid scintillation counting of emulsions. Analytical Chemistry 37, 854-857.

Ramos, S., Schuldiner, S. \& Kaback, H. R. (1976). The electrochemical gradient of protons and its relationship to active transport in Escherichia coli membrane vesicles. Proceedings of the National Academy of Sciences of the United States of America 73, 1892-1896.

REINER, A. M. (1971). Metabolism of benzoic acid by bacteria: 3,5-cyclohexadiene-1,2-diol-1-carboxylic acid is an intermediate in the formation of catechol. Journal of Bacteriology 108, 89-94.

Reiner, A. M. \& Hegeman, G. D. (1971). Metabo- lism of benzoic acid by bacteria. Accumulation of 3,5-cyclohexadiene-1,2-diol-1-carboxylic acid by a mutant strain of Alcaligenes eutrophus. Biochemistry 10, 2530-2536.

Reynafarje, B., Brand, M. D. \& Lehninger, A. L. (1976). Evaluation of the $\mathrm{H}^{+} /$site ratio of mitochondrial electron transport from rate measurements. Journal of Biological Chemistry 251, 74427451.

Robertson, H. E. \& Boyer, P. D. (1955). The effect of azide on phosphorylation accompanying electron transport and glycolysis. Journal of Biological Chemistry 214, 295-305.

Rosenberg, H., Gerdes, R. G. \& Chegwidden, K. (1977). Two systems for the uptake of phosphate in Escherichia coli. Journal of Bacteriology 131, 505-511.

ROTTENBERG, H. (1975). The measurement of transmembrane electrochemical proton gradients. Journal of Bioenergetics 7, 61-74.

Stanier, R. Y., Palleroni, N. J. \& Doudoroff, M. (1966). The aerobic pseudomonads: a taxonomic study. Journal of General Microbiology 43, 159271.

StinNet, J. D. \& EAGon, R. G. (1975). A model system for studying protein-lipopolysaccharide synthesis, assembly, and insertion in the outer membrane of Pseudomonas aeruginosa. Canadian Journal of Microbiology 21, 1834-1841.

Thayer, J. R. \& Wheelis, M. L. (1976). Characterization of a benzoate permease mutant of Pseudomonas putida. Archives of Microbiology 110 , 37-42.

WheElis, M. L. \& OrNSton, L. N. (1972). Genetic control of enzyme induction in the $\beta$-ketoadipate pathway of Pseudomonas putida: deletion mapping of cat mutations. Journal of Bacteriology 109, 790-795. 